\title{
Sponge/coral interactions in Caribbean reefs: analysis of overgrowth patterns in relation to species identity and cover
}

\author{
L. A. M. Aerts* \\ Institute of Systematics and Population Biology, University of Amsterdam, pO Box 94766, 1090 GT \\ Amsterdam, The Netherlands"* \\ CARMABI Foundation - Ecological Institute, PO Box 2090, Curaçao, Netherlands Antilles \\ and \\ Instituto de Investigaciones Marinas Punta de Betin, A.A. 1016 Santa Marta, Colombia (S.A.)
}

\begin{abstract}
Coral overgrowth by sponge species was studied on Caribbean reefs to determine whether it depends on coral cover and species composition. Overgrowth was quantified in belt transects at 4 localities on the reefs of Curaçao (Netherlands Antilles) and compared to 5 localities sampled on Colombian reefs. Coral perimeter, coral cover, sponge cover, sponge abundance and species richness were measured at each locality. The species richness of aggressive sponges was not influenced by coral cover, whereas the species richness of non aggressive sponges decreased with increasing coral cover. At coral covers of $>25 \%$, the sponge community was characterised by more aggressive species. This is a clear example of the importance of spatial competition, indicating that only aggressive sponge species are able to survive on reefs with high coral cover. Below $25 \%$ coral cover, the increasing presence of aggressive sponge species resulted in an increasing number of overgrowth interactions. At higher coral cover this relation is distorted. The average coral cover was significantly higher on the reefs of Curaçao than on the Colombian reefs. As a consequence, more sponge species were involved in overgrowth interactions on Curaçao than on Colombian reefs. The importance of this overgrowth capacity is emphasised by the impact of sponge species composition. The occurrence of coral overgrowth was dependent on the sponge species composition rather than on the abundance of sponge species. The coral species composition did not influence the frequency of sponge/coral overgrowth interactions. I conclude that competition for space between sponges and corals is important on reefs with high coral cover as more aggressive sponge species and hence more overgrowth interactions occur Successful overgrowth of corals by sponges depends on coral cover (irrespective of coral species) and sponge species composition.
\end{abstract}

KEY WORDS: Coral reef - Caribbean - Sponges - Corals - Spatial competition - Interactions - Overgrowth

\section{INTRODUCTION}

Variations in species diversity, distribution and abundance on a coral reef are often attributed to processes occurring within the community such as competition and predation (e.g. Sammarco 1982, Connell 1983, Schoener 1983, Sih et al. 1985, Lewis 1986) and physical disturbances (review by Karlson \& Hurd 1993). The importance of each of the processes

- E-mail: lispete@ibm.net

- Address for correspondence remains controversial. In coral reef communities the significance of competition between the major bottom components has been discussed by various authors (Benayahu \& Loya 1981, Bak et al. 1982, Bradbury \& Young 1983, Suchanek et al. 1983, Sammarco et al. 1985, Lang \& Chornesky 1990). Most of these studies tried to demonstrate the ecological importance of competition or to detect complex competitive networks in order to explain species diversity of the community (also Lang 1973, Russ 1982). These competitive networks are likely the result of evolution between interacting species: any species can evolve in response to 
direct interactions by changing its response to or its effect on another species (Menge 1995, Miller \& Travis 1996). This results in a variety of competitive mechanisms displayed by species within the same group or between groups (Sullivan et al. 1983, Sammarco et al. 1985, Lang \& Chornesky 1990). The competitive success of a species often depends on the defensive or offensive mechanism employed. Although a major part of the benthic biota on coral reefs consist of sponges, which play an important role in spatial competition (Suchanek et al. 1983), little is known about sponge/coral interactions.

Corals compete by means of a variety of direct and indirect mechanisms (reviewed by Lang \& Chornesky 1990 ) or in the long term by redirection of growth (Romano 1990). Sponges lack specific competitive organs but often possess biologically active substances (Thompson 1985, Walker et al. 1985, Schulte et al. 1991) which can damage their neighbours (e.g. Sullivan et al. 1983, Targett 1988, Aerts \& van Soest unpubl.) even in non contact situations (Porter \& Targett 1988). Sponge species have been found to compete successfully with corals (Suchanek et al. 1983, Porter \& Targett 1988, Vicente 1990, Rützler \& Muzik 1993). Those studies mainly focused on 1 species and informed us about the effect of sponges on corals and identified winners and losers. On a Colombian reef, overgrowth activities of a variety of reef sponges have been quantified and explained by differences in the physical environment (Aerts \& van Soest 1997). The impact of the physical environment is possibly equivocal as higher overgrowth frequencies of corals in polluted Pacific reef environments (Rützler \& Muzik 1993) have not been found in the physically stressed Colombian Caribbean (Aerts \& van Soest 1997). This contradictory result may be scale dependent or caused by differences in sponge species studied.

The outcome of competitive interactions between coral colonies is influenced by a variety of factors, such as distance between competing species and species identity (Lang \& Chornesky 1990). Coral species vary enormously in their competitive capability (Lang 1973), and species identity is one of the factors determining the outcome of encounters between corals. In sponge/coral interactions a competitive dominance of sponges has been demonstrated in several studies (Russ 1982, Suchanek et al. 1983, Nandakumar et al. 1993). Most sponge species studied competed successfully with a variety of coral species. Besides differences in susceptibility, overgrowth frequency of coral species by sponges appear to depend on the frequency of encounter with aggressive sponge species (Aerts \& van Soest 1997). Also, more coral cover results in more overgrowth interactions in one of the most aggressive sponge species (Aerts \& van Soest 1997). To determine the role of coral and sponge species composition and cover on the occurrence of overgrowth interactions, reefs with different coral and sponge distributions and cover need to be compared.

In the present study, I quantified coral overgrowth by sponges on the reefs of Curaçao (a relatively undisturbed reef environment with high coral cover; Netherlands Antilles) and compared (and combined) the results with the occurrence of coral overgrowth found on the physically stressed continental Colombian reefs. The aim was to determine: (1) the relation between sedimentation stress and the frequency of coral overgrowth by sponges, (2) the relation between coral cover and the overgrowth frequency of corals by sponges, and (3) the relation between coral and sponge species composition and the frequency of coral overgrowth by sponges.

\section{MATERIALS AND METHODS}

Study area. The environmental conditions on the Caribbean reefs of Curaçao and Santa Marta, NE Colombia (Fig. 1), are completely different. In Curaçao sea temperature ranges between 25 and $29^{\circ} \mathrm{C}$ and changes in salinity are negligible (van Duyl 1985). In Santa Marta, temperatures can drop to $21^{\circ} \mathrm{C}$ and salinity can rise to $37 \%$ due to upwelling of cold water (Zea 1987). Temperatures can increase to $30^{\circ} \mathrm{C}$ and the influence of freshwater can cause a decrease in salinity to $29 \%$ or less (Bula 1977, Müller 1979). There are high

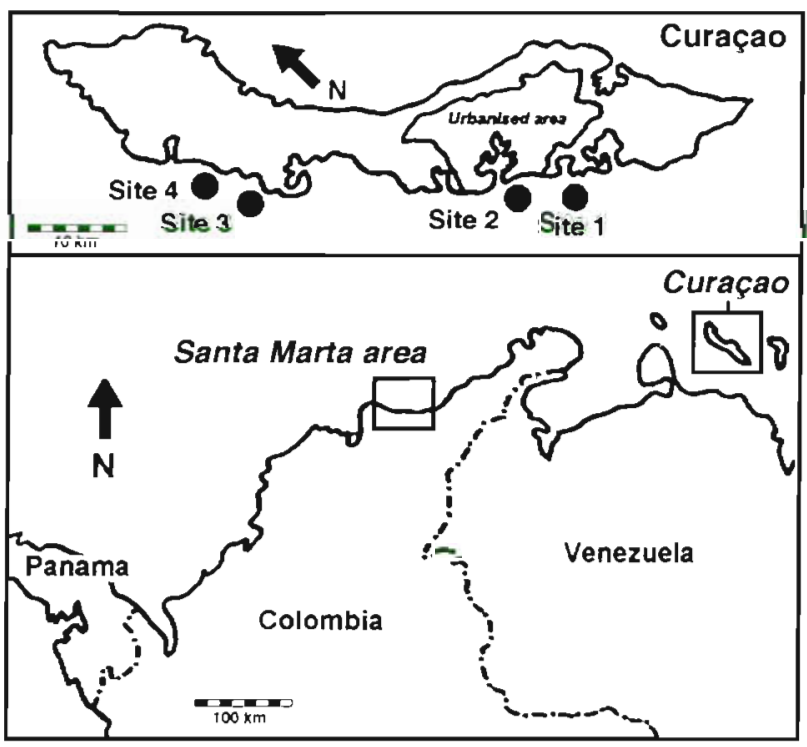

Fig. 1. Overview of the South Caribbean with the island of Curaçao and the Santa Marta area, NE Colombia, (-) Sampled sites 
sediment loads through terrigenous effluents. Consequently, the coastal reefs of Santa Marta are not as well developed as those in other areas of the Caribbean (Von Prahl \& Erhardt 1985, Zea 1994) and are a great contrast to the reefs of Curaçao.

The sediment load on the reefs of Curaçao (4 localities, 3 depths) was measured, as in the Santa Marta area, using PVC sediment traps with a ratio between length and diameter of 5:1 (Gardner 1980, Larsson et al. 1986). Sediment rates measured in this study include the effect of local sediment resuspension. The traps were collected monthly between August 1995 and February 1996 (6 samples per station). Although a considerable overlap in sedimentation among the stations of both reefs exists (range Curaçao 5.5 to $70.2 \mathrm{~g} \mathrm{~m}^{-2} \mathrm{~d}^{-1}$, range Colombia 15.0 to $132.0 \mathrm{~g} \mathrm{~m}^{-2} \mathrm{~d}^{-1}$ ), the average sediment load was significantly higher for Colombia $\left(44.6 \pm 8.7 \mathrm{~g} \mathrm{~m}^{-2} \mathrm{~d}^{-1}\right)$ than for Curaçao $\left(18.1 \pm 5.6 \mathrm{~g} \mathrm{~m}^{-2}\right.$ $\mathrm{d}^{-1}$ ) (Kruskall-Wallis $\mathrm{p}=0.002$ ).

Quantification of sponge/coral encounters. On the reefs of Curaçao 4 localities and 3 depths were sampled for sponge/coral encounters and compared with 5 localities sampled at the same 3 depths on the reefs of the Santa Marta area, (Aerts \& van Soest 1997) (Fig. 1). Belt transects of $10 \mathrm{~m}$, attached to a randomly chosen point and stretched out parallel to 5, 10 and $20 \mathrm{~m}$ isobaths, were used to quantify sponge/coral encounters. At each station, three $10 \mathrm{~m}^{2}$ transects were surveyed. At one site (Daaibooibaai) the $5 \mathrm{~m}$ isobath covered mainly sand and was not sampled. On the Curaçao reefs $330 \mathrm{~m}^{2}$ was sampled for the presence of sponge/ coral encounters. The total sampling area covered at both Caribbean reefs was $780 \mathrm{~m}^{2}$ (26 stations).

Since the interactive reach of many corals lies in the 1 to $5 \mathrm{~cm}$ range (Richardson et al. 1979, Sheppard 1981) and sponges are able to affect corals even in non contact situations (Porter \& Targett 1988), each sponge encountered within $5 \mathrm{~cm}$ from a coral was considered as a partner in an interaction. Four categories of encounters were defined (for explanation and illustration see Aerts \& van Soest 1997). In this study, I focused only on overgrowth interactions. In each belt transect the total number of sponge individuals and coral colonies, the total coral perimeter for each species and the total cover (in \%) of sponges, corals and sand were noted and averaged for the 3 belt transects taken at each station. The interacting sponge and coral species were identified to species level.

Statistics. Because sponge species richness never reached zero, a theoretical model which included an asymptote proved to give the best approximation for the dataset. The equation of this model is:

species richness $=$ asymptote +

$$
\text { [richness } \left.\max . \times 10^{\text {(slope } \times \text { coral cover }}\right]
$$

in which species richness is the number of non aggressive species; the asymptote is the minimum number of non aggressive species present with increasing coral cover; richness mox $_{\text {. }}$ is the number of non aggressive sponge species which theoretically can be reached in the sampled area; slope is the regression slope. The non linear iterative fitting method used the above function and the Simplex least-squares method (Wilkinson 1989). This regression model was also successfully used in a study describing regeneration processes in corals (Meesters et al. 1994). The other variables were analysed using linear regressions. Assumptions for the use of regression were checked by residual plots (Wilkinson 1989) and data were transformed when necessary. Differences in variable means among the stations of the 2 Caribbean reefs were tested by single classification ANOVA with $\log (10 x)$ (coral cover, number of overgrowths $\mathrm{m}^{-2}$ ) and $\log (x)$ (sedimentation) transformed data (Sokal \& Rohlf 1981). When necessary multiple comparisons of means were performed using the Tukey-Kramer method (Sokal \& Rohlf 1981).

\section{RESULTS}

\section{Overgrowth, sponge species richness and coral cover}

A total of 246 overgrowth interactions of corals by sponges were sampled in $780 \mathrm{~m}^{2}$ at 26 stations on the reefs of Curaçao and Colombia. This is an average of 0.32 overgrowth interactions $\mathrm{m}^{-2}$, which means that in each $3 \mathrm{~m}^{2}$ an interaction involving the overgrowth of a coral by a sponge occurs. Of the 128 sponge species involved in sponge/coral encounters 30 (=23.4\%) were engaged in overgrowth interactions and considered as aggressive. The presence of aggressive sponge species (in \% of the total number of sponge species) increased with increasing coral cover until a cover of approximately $25 \%$ was reached (Fig. 2A). This increase was caused by a decline in the number of non aggressive sponge species (Fig. 2B). Beyond $25 \%$ coral cover the species richness (in number) of non aggressive sponge species remained the same. The species richness of aggressive sponge species was independent of coral cover (Fig. 2C). The relatively increasing presence of aggressive sponge species influenced the correlation between coral cover and the occurrence of overgrowth interactions. Below 25\% cover, the number of overgrowth interactions increased with increasing coral cover. When the coral cover exceeded $25 \%$, no correlation was apparent between the number of overgrowth interactions and coral cover (Fig. 3). Because of the positive correlation between coral cover and 


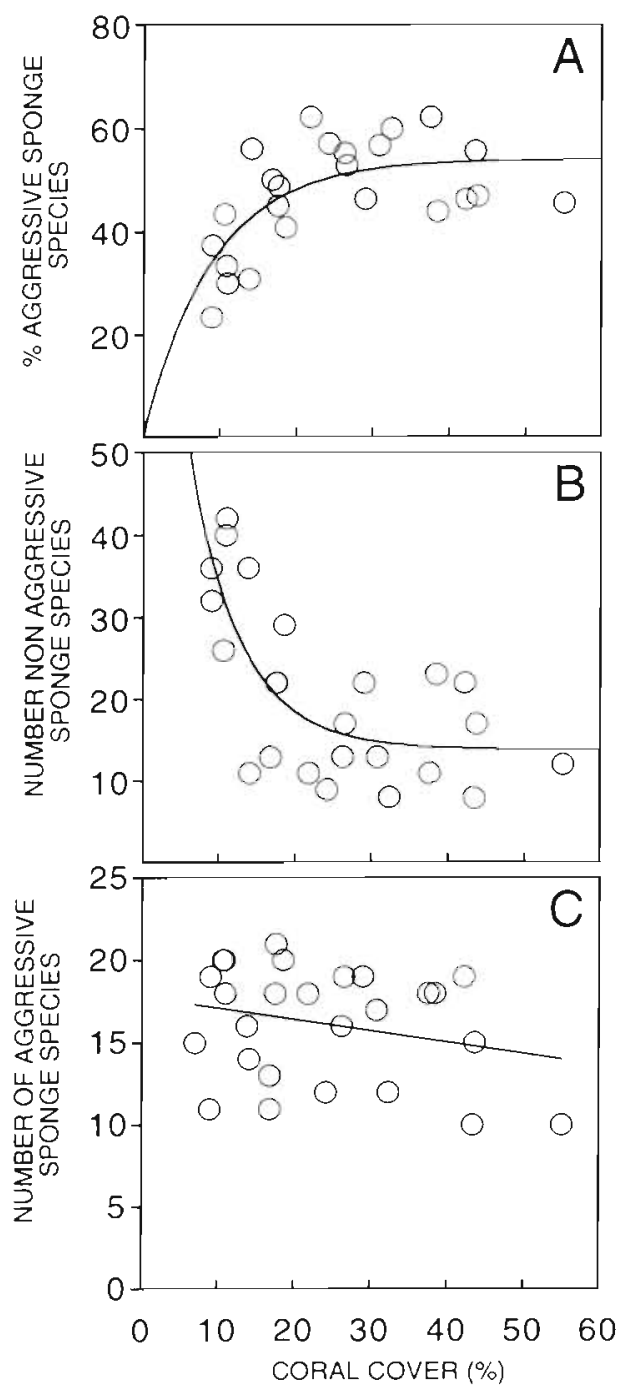

Fig. 2. Sponge species richness (in number of species $\mathrm{m}^{-2}$ ) and coral cover for all sites and depths. (A) Relative presence of aggressive sponge species (in \% of total number of sponge species $\}$. Estimated non linear regression line: $y=54.0-(54.0$ $\times 10^{-0.05 x}, R^{2}=0.49$. (B) Number of non aggrescive sponge species. Estimated non linear regression line: $y=13.8+(88.7$ $\times 10^{-0.06 x}, R^{2}=0.56$ (C) Number of aggressive sponge species. Line fitted the linear model: $y=17.7-0.07 x, \mathrm{R}^{2}=0.07$

perimeter $\left(R^{2}=0.79, p<0.001\right)$, the abovementioned results were also found using coral perimeters. Abundance of aggressive sponge specimens and sedimentation load were not significantly correlated with the occurrence of overgrowth interactions $\left(R^{2}=0.033, p=\right.$ 0.371 and $R^{2}=0.017, p=0.531$ respectively).

\section{Overgrowth and species identity}

On the reefs of Curaçao 68 sponge species and 22 coral species were engaged in sponge/coral encoun- ters. A higher proportion of sponge species was encountered in overgrowth interactions and hence considered aggressive compared to the Colombian reef $(33.8 \%$ vs $15.8 \%$ of total number of sponge species respectively). There was a significant difference in number of overgrowth interactions $\mathrm{m}^{-2}$ between the reefs of Curaçao and Colombia $(0.46 \pm 0.26$ vs $0.21 \pm$ 0.15 overgrowth interactions $\mathrm{m}^{-2}$ respectively) (ANOVA $\mathrm{p}=0.005$ ). The higher number of overgrowth interactions and higher percentage of aggressive sponge species on Curaçao can be explained by the difference in average coral cover on both reefs. Although there is an overlap in coral cover among the stations of both reefs (range Curaçao 17.5 to $55.1 \%$. range Colombia 7.0 to $42.1 \%$ ), the average coral cover was higher on Curaçao than on Colombian reefs (31.6 $\pm 13.9 \%$ vs $18.4 \pm 11.2 \%$, ANOVA $p=0.008)$.

All sponge species, except those which were not or only sporadically observed (see Table 1), were found to overgrow corals more frequently on Curaçao than on Colombian reefs (Fig. 4). Between sponge species, a great difference in overgrowth ability can be seen. The most aggressive sponge species on both Caribbean reefs is Desmapsamma anchorata. On the reefs of Curaçao 5 other sponge species (Aplysina fulva, A lacunosa, Callyspongia fallax, Neofibularia nolitangere and Verongula rigida) displayed rather high overgrowth frequencies $(\geq 30 \%)$.

More coral species were overgrown by sponges on Curaçao (17 species, which is $77.3 \%$ of total number of coral species) than on Colombian (12 species, i.e. $57.1 \%$ of total number of coral species) (Fig. 5). On the Colom-

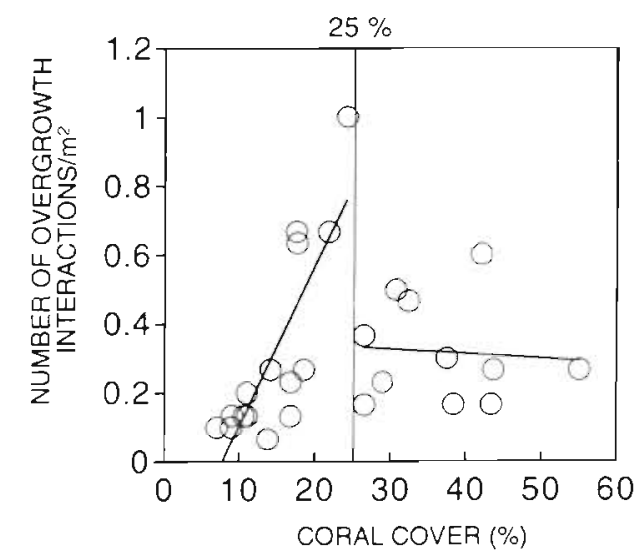

Fig. 3. Number of overgrowth interactions $\left(\mathrm{m}^{-2}\right)$ and mean coral cover (in \%) for all sites and depths. The lines fitted the linear model: number of overgrowth interactions $=a+b \times$ coral cover (O) with $a=-0.36$, slope $=0.05, R^{2}=0.66, p<0.001$ for the stations with a coral cover below $25 \%$ and $a=0.37$, slope $=0.001, R^{2}=0.006, p=0.818$ for all stations with a coral cover above $25 \%$ 
OCCURRENCE $(\%) \quad$ OCCURRENCE $(\%)$

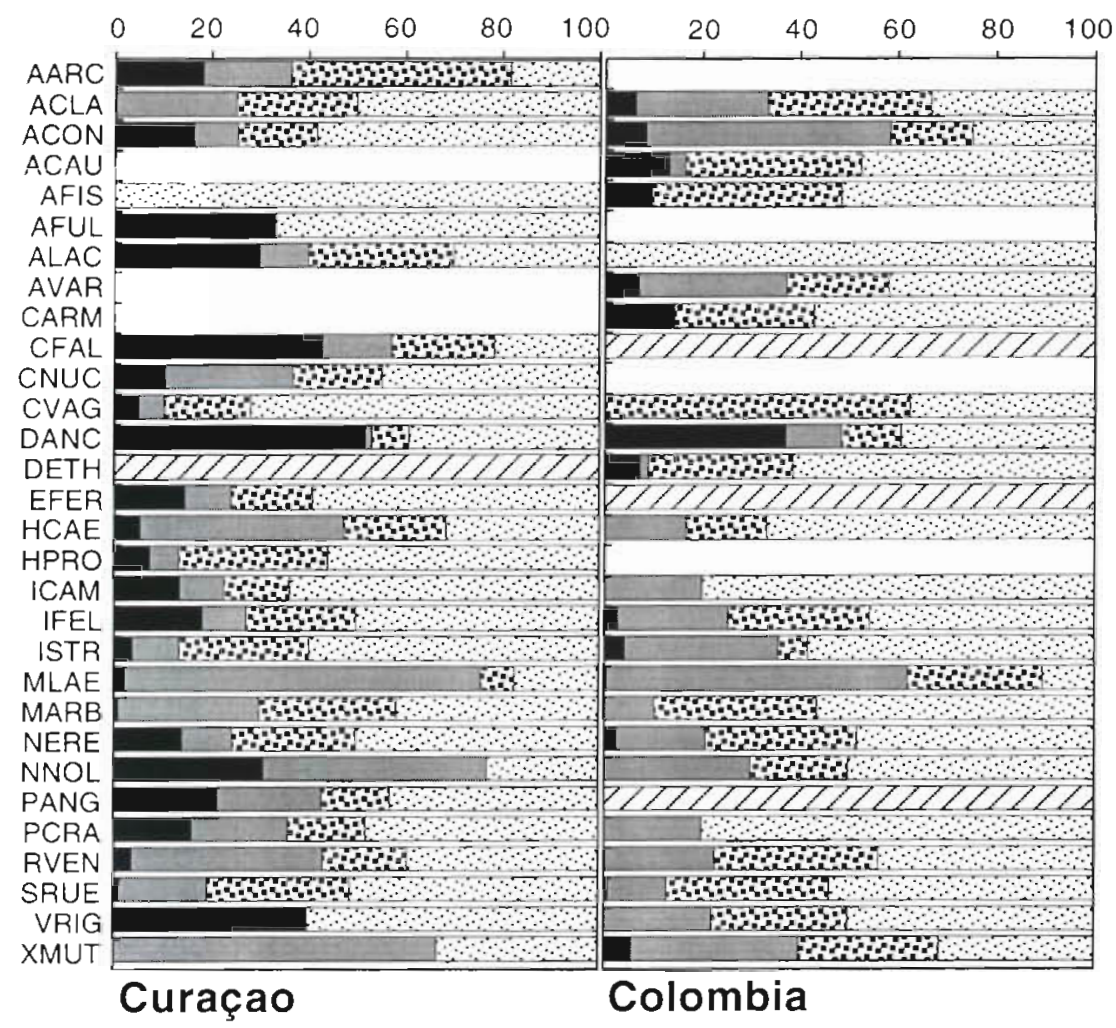

Fig. 4. Frequency of interaction categories in \% of total number of encounters, for each sponge species on Curaçao and Colom-

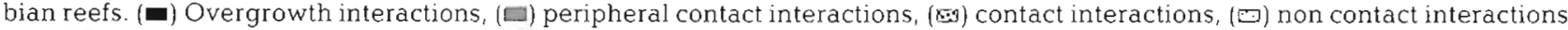
and $(\square)$ species was present on the reef but no encounters with corals were observed. For abbreviations of species names see Table 1

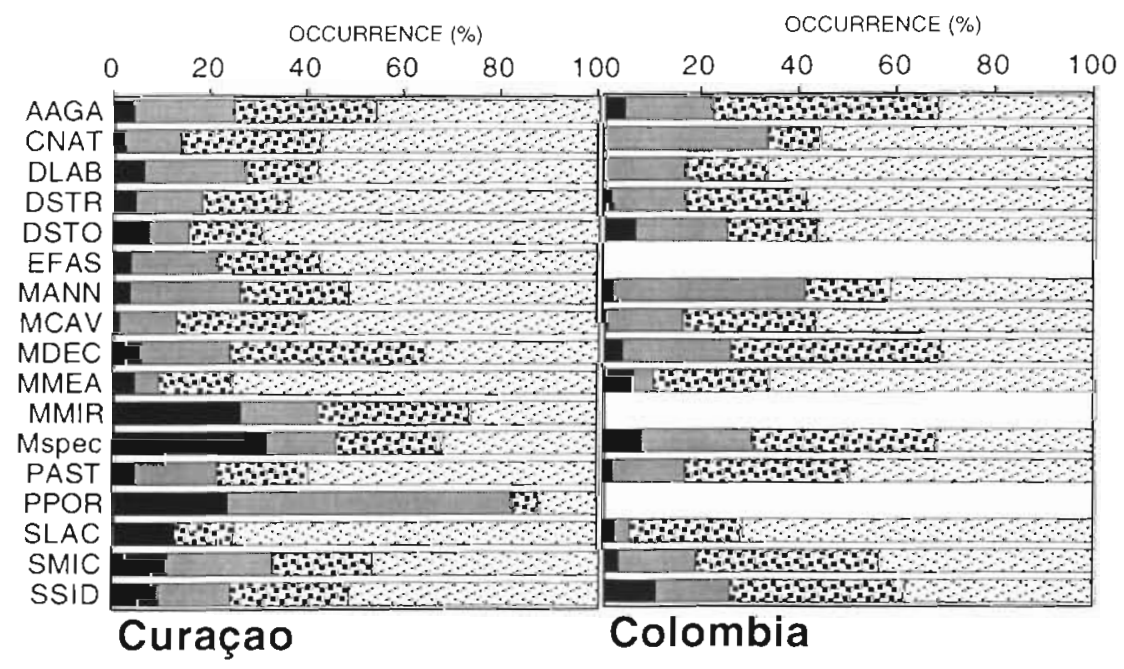

Fig. 5. Frequency of each interaction category in \% of total number of encounters for each coral species on Curaçao and Colombian reefs. ( $\square)$ Overgrowth interactions, $(\square)$ peripheral contact interactions, ( $\square)$ contact interactions, (অ) non contact interactions and (Za) species was present on the reef but no encounters with corals were observed. AAGA: Agaricia agaricites; CNAT: Colpophyllia natans; DLAB: Diploria labyrinthiformis; DSTR: Diploria strigosa; DSTO. Dichocoenia stokesi; EFAS: Eusmillia fastigiata; MANN: Montastrea annularis; MCAV: Montastrea cavernosa; MDEC: Madracis decactis; MMEA: Meandrina meandrites; MMIR: Madracis mirabilis; Mspec: Millepora spp.; PAST: Porites astreoides; PPOR: Porites porites; SI AC: Scolymia Iacera; SMIC: Stephanocoenia michelini and SSID Siderea siderastrea 
Table 1 Presence and the total number of interactions for each sponge species for the reefs of Curaçao and Colombia. n: total number of sponge specimens; Enc.: total number of encounters (all categories) found in the sampling area. Enc. ind ${ }^{-1}$ : the number of encounters per sponge specimen

\begin{tabular}{|c|c|c|c|c|c|c|c|}
\hline \multirow[t]{2}{*}{ Species } & \multirow{2}{*}{$\begin{array}{l}\text { Species } \\
\text { abbreviation }\end{array}$} & \multicolumn{3}{|c|}{ Curaçao } & \multicolumn{3}{|c|}{ Colombia } \\
\hline & & $\mathrm{n}$ & Enc. & Enc. ind. ${ }^{-1}$ & $\mathrm{n}$ & Enc. & Enc. ind. ${ }^{-1}$ \\
\hline Aplysina archeri & AARC & 13 & 11 & 0.85 & 0 & 0 & 0 \\
\hline Aplysina cauliformis & $A C A U$ & 0 & 0 & 0 & 365 & 122 & 0.33 \\
\hline Agelas clathrodes & ACLA & 15 & 4 & 0.27 & 105 & 33 & 0.31 \\
\hline Agelas conifera & $\mathrm{ACON}$ & 57 & 67 & 1.18 & 45 & 12 & 0.27 \\
\hline Aplysina fistularis & AFIS & 1 & 1 & 1.00 & 111 & 31 & 0.28 \\
\hline Aplysina fulva & AFUL & 7 & 3 & 0.43 & 0 & 0 & 0 \\
\hline Aplysina lacunosa & ALAC & 27 & 10 & 0.37 & 9 & 2 & 0.22 \\
\hline Anthosigmella varians & AVAR & 0 & 0 & 0 & 56 & 43 & 0.77 \\
\hline Callyspongia armigera & CARM & 0 & 0 & 0 & 13 & 7 & 0.54 \\
\hline Callyspongia fallax & CFAL & 1.7 & 14 & 0.82 & 1 & 0 & 0 \\
\hline Chondrilla nucula & CNUC & 62 & 38 & 0.61 & 0 & 0 & 0 \\
\hline Callyspongia vaginalis & CVAG & 50 & 39 & 0.78 & 17 & 8 & 0.47 \\
\hline Desmapsamma anchorata & DANC & 152 & 79 & 0.52 & 232 & 89 & 0.38 \\
\hline Dysidea etheria & DETH & 5 & 0 & 0.00 & 618 & 1.11 & 0.18 \\
\hline Ectyoplasia ferox & EFER & 111 & 83 & 0.75 & 4 & 2 & 0.50 \\
\hline Halisarca caerulea & $\mathrm{HCAE}$ & 20 & 19 & 0.95 & 19 & 6 & 0.32 \\
\hline Hyrtios proteus & HPRO & 84 & 68 & 0.81 & 0 & 0 & 0 \\
\hline Ircinia campana & ICAM & 20 & 22 & 1.10 & 11 & 5 & 0.45 \\
\hline Ircinia felix & IFEL & 22 & 23 & 1.05 & 489 & 223 & 0.46 \\
\hline Ircinia strobilina & ISTR & 60 & 52 & 0.87 & 107 & 48 & 0.45 \\
\hline Monanchora arbuscula & MARB & 173 & 120 & 0.69 & 240 & 78 & 0.33 \\
\hline Mycale laevis & MLAE & 38 & 41 & 1.08 & 194 & 182 & 0.94 \\
\hline Niphates erecta & NERE & 368 & 201 & 0.55 & 1122 & 328 & 0.29 \\
\hline Neofibularia nolitangere & NNOL & 16 & 13 & 0.81 & 19 & 10 & 0.53 \\
\hline Plakortis angulospiculatis & PANG & 1.9 & 14 & 0.74 & 8 & 0 & 0 \\
\hline Pseudoceratina crassa & PCRA & 36 & 25 & 0.69 & 20 & 5 & 0.25 \\
\hline Raphidophlus venosus & RVEN & 116 & 81 & 0.70 & 988 & 424 & 0.43 \\
\hline Scopalina ruetzleri & SRUE & 1799 & 823 & 0.46 & 3607 & 1089 & 0.30 \\
\hline Verongula rigida & VRIG & 8 & 5 & 0.63 & 48 & 18 & 0.38 \\
\hline Xestospongia muta & XMUT & 4 & 3 & 0.75 & 75 & 35 & 0.47 \\
\hline Average & & & & 0.65 & & & 0.33 \\
\hline $\pm S D$ & & & & \pm 0.34 & & & \pm 0.23 \\
\hline
\end{tabular}

bian reef differences in susceptibility to sponge overgrowth between coral species were not as obvious as on the reefs of Curaçao. The hydrocorals of the genus Millepora and the branching coral species Madracis mirabilis and Porites porites were clearly most susceptible to sponge overgrowth on the Curaçao reefs (Fig. 5).

Comparison of overgrowth frequency for each sponge species with only those coral species shared between the 2 reef communities also resulted in a higher overgrowth frequency of sponge species on the reefs of Curaçao. This means that differences in overgrowth frequency were not caused by the coral species composition. As a consequence of the higher coral cover, sponge specimens were significantly more confronted with corals on the reefs of Curaçao than on Colombian reefs, as is shown by the higher. number of encounters per specimen (Table 1 ).

Because most sponge species show a depth related distribution pattern (Alcolado 1.994, Aerts et al. unpubl.), the importance of sponge species composition to the overgrowth frequency was assessed by cal-

Table 2. Overgrowth frequency (in \% of total number of encounters) for each depth for the reefs of Curaçao and Colombia and for both reefs combined. Depth related differences wcre tested with ANOVA and the Tukey-Kramer method (multiple comparison of means) p: probabilities of the test; " significant difference at the $5 \%$ level.

\begin{tabular}{|lrrr|}
\hline \multicolumn{1}{l}{ Depth } & \multicolumn{1}{c}{ Curaçao } & Colombia & Both reefs \\
\hline \multicolumn{2}{l}{ Overgrowth frequency } & & \\
$5 \mathrm{~m}$ & $14.1( \pm 4.06)$ & $4.8( \pm 1.97)$ & $8.3( \pm 2.12)$ \\
$10 \mathrm{~m}$ & $7.0( \pm 1.42)$ & $2.3( \pm 0.58)$ & $4.4( \pm 0.83)$ \\
$20 \mathrm{~m}$ & $3.9( \pm 0.64)$ & $1.2( \pm 0.33)$ & $2.4( \pm 0.42)$ \\
Tukey-Kramer method & & \\
$5 \mathrm{~m}-10 \mathrm{~m}$ & $\mathrm{p}=0.077$ & $\mathrm{p}=0.146$ & $\mathrm{p}=0.174$ \\
$5 \mathrm{~m}-20 \mathrm{~m}$ & $\mathrm{p}=0.008$ & $\cdot p=0.012$ & $\cdot p=0.031$ \\
$10 \mathrm{~m}-20 \mathrm{~m}$ & $\mathrm{p}=0.547$ & $\mathrm{p}=0.359$ & $\mathrm{p}=0.584$ \\
\hline
\end{tabular}




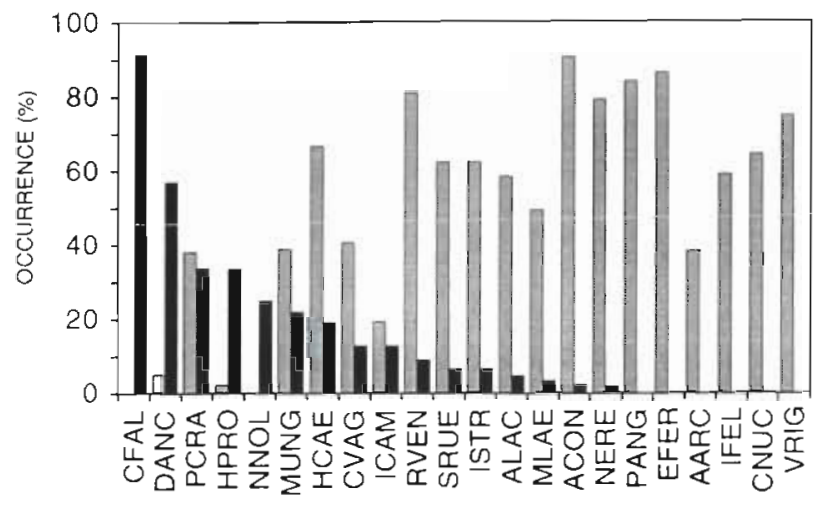

Fig. 6. Purcentage occurrence, out of the total number of sponge specimens at $5 \mathrm{~m} \mathrm{( \square )}$ and $20 \mathrm{~m}$ depth (口). For abbreviations of sponge species names see Table 1

culating depth related differences of overgrowth. In these calculations relative frequencies were used because these percentages were corrected for sponge and coral cover. Depth related differences were found with data from both reefs and from each reef separately (ANOVA $p<0.05$; Table 2). The higher overgrowth frequency at $5 \mathrm{~m}$ depth can be explained by the fact that the most aggressive sponge species on both reefs, Desmapsamma anchorata, occurs mainly at this depth (Aerts \& van Soest 1997, Aerts et al. unpubl., Fig. 6).

\section{DISCUSSION}

\section{Overgrowth and coral cover}

Inherent to stress of coral reef communities is the basic concept that stress puts them at an energetic disadvantage which interferes with the normal function of the system and affects the community structure of coral assemblages (Cortés \& Risk 1984, Tomascik \& Sander 1987, Edmunds 1989). Decline in the energy budget of corals affects their competitive ability (Aerts unpubl.). In environments with increased nutrient levels coral competition with macro algae and sponges may limit coral growth by overgrowth of corals and hence reduce coral diversity and cover (Johannes et al. 1983, Rützler \& Muzik 1993, Fraser \& Currie 1996). Compared with Curaçao, the Colombian reef can be characterised as stressed. Because of its higher sediment load, it has lower coral species diversity, less live coral cover and less abundance of growth forms (see review by Rogers 1990, Zea 1994). Despite these differences, the stations sampled within these 2 reefs show an overlap in variables such as coral cover, sedimentation and species composition. We found, on a regional scale (Aerts \& van Soest 1997) and on a geo- graphical scale (this study), no direct relation between sediment stress for corals and frequency of overgrowth by sponges. The total occurrence of coral overgrowth by sponges on the reef of Curaçao was found to be a good 2 times higher than on the relatively stressed Colombian reef.

In this study I found that competitively weak sponge species disappear first on reefs with high coral cover and limited space. The sponge community was characterised by having more aggressive species at coral covers $>25 \%$. Apparently, only competitively dominant sponge species are able to maintain space in coral reef environments with high mean coral cover, because they are better equipped to defend their position on the reef (Aerts \& van Soest unpubl.).

The aggressive sponge species richness influences the occurrence of overgrowth. The number of overgrowth interactions was positively correlated with coral covers $<25 \%$. Above $25 \%$ coral cover the portion of aggressive sponge species remained constant, and also the correlation between coral cover and overgrowth was distorted. The abundance of aggressive sponge specimens did not influence the number of overgrowth interactions. Only the sponge species composition was important (discussed below). I conclude that the higher number of overgrowth interactions and higher portion of aggressive sponge species on the reef of Curaçao are caused by higher average coral cover.

\section{Overgrowth and species composition}

Up to this point we haved focused on the overall occurrence of overgrowth on both reefs without looking at the level of the interacting species. Comparison of overgrowth frequency for each sponge species separately between the Curaçao and Colombian reefs revealed again higher overgrowth frequencies for the reefs of Curaçao. Explanations for this could be a difference in sponge functioning due to environmental conditions, a difference in coral species composition or a difference in coral cover.

Polluted and stressed reef environments exhibit higher sponge biomass (Wilkinson \& Cheshire 1990) as is clearly demonstrated by the higher sponge cover on the physically stressed Colombian reef. Interaction experiments with 2 specific sponge species showed obvious differences in the reaction of the sponges to the proximity of corals (Aerts et al. unpubl.). These species specific reactions to competing neighbours is also shown by differences in competitive ability between sponge species. The depth related differences in overgrowth clearly show the importance of sponge species distribution to the occurrence of overgrowth interactions. 
On both reefs a distinct hierarchy in susceptibility of corals to sponge overgrowth, as observed in coral/coral interactions (Lang 1973, Bak et al. 1982, Logan 1984), was not found. This is partly due to the fact that chance of encounters with aggressive sponge species determined differences in susceptibility of corals (Aerts \& van Soest 1997). On the Curaçao reef, the susceptibility to sponge overgrowth of the ramose corals Madracis mirabilis and Porites porites and corals of the genus Millepora formed a striking contrast with the other coral species. Except for Millepora spp., these species were not common on the Colombian reef (Aerts \& van Soest 1997). Apart from a low competitive ability of these ramose corals (Lang 1973), the high susceptibility to sponge overgrowth very likely results from a large circumference relative to the colony surface area. A relatively high circumference:surface ratio means a higher probability of interaction (Van Veghel et al. 1996) and an increasing susceptibility to partial mortality (Hughes 1996, Meesters et al. 1997). In our case the difference in overgrowth frequency by individual sponge species on both reefs was not caused by the coral species composition. The overgrowth frequency remained higher on the reefs of Curaçao when only the coral species shared between the 2 reef communities were taken into account.

On the reefs of Curaçao, more encounters with corals occurred per sponge individual than on the Colombian reef. Most organisms try to reduce the impact of competition by growing along margins which are not in close proximity to potential competitors (Lang \& Chornesky 1990, Romano 1990). A higher coral cover increases chance of encounters between sponges and corals and enhances the overgrowth frequency of aggressive sponge species. On a community level, this study demonstrated that the extent to which coral overgrowth occurs depends on the competitive ability of sponges and coral cover

I conclude that spatial competition between sponges and corals is important on reefs with high coral cover. More aggressive sponge species and hence more overgrowth interactions occur on well developed reefs. Successful overgrowth of corals by sponges depends on coral cover (irrespective of coral species) and sponge species composition.

Acknowledgements. I thank Dr R. W. M. van Soest (University of Amsterdam [UvA]) and Prof. R. P. M. Bak (UvA, Netherlands Institute for Sea Research) for their support and for critically reading the manuscript. I thank the CARMABI. Institute (Curaçao) and INVEMAR (Colombia) for their logistic support and the Netherlands Institute for Sea Research for use of facilities. This research was made possible by a grant from the Netherlands Organisation for Scientific Research in the tropics (WOTRO, project no. W84-342).

\section{LITERATURE CITED}

Aerts LAM, van Soest RWM (1997) Quantification of sponge/ coral interactions in a physically stressed reef community, NE Colombia. Mar Ecol Prog Ser 148:125-134

Alcolado PM (1994) General trends in coral reef sponge communities of Cuba. In: van Soest RWM van Kempen ThMG, Braekman JC (eds) Sponges in time and space. Balkema, Rotterdam, p 257-264

Bak RPM, Termaat RM, Dekker R (1982) Complexity of coral interactions: influence of time, locality of interaction and epifauna. Mar Biol 69:215-222

Benayahu Y, Loya Y (1981) Competition for space among coral-reef sessile organisms at Eilat, Red Sea. Bull Mar Sci 31:514-522

Bradbury RH, Young PC (1983) Coral interactions and community structure: an analysis of spatial pattern. Mar Ecol Prog Ser 11:265-271

Bula G (1977) Algas marinas bénticas indicadoras de un área afectada por aguas de surgencia en la Costa Caribe de Colombia. An Inst Inv Mar Punta Betín 9:45-7.1

Connell JH (1983) On the prevalence and relative importance of interspecific competition: evidence from field experiments. Am Nat 122:661-696

Cortés J, Risk M (1984) A reef under siltation stress: Cahuita, Costa Rica. Bull Mar Sci 36:339-356

Edmunds PJ (1989) An energy budget for Porites porites (Scleractinia), growing in a stressed environment. Coral Reefs 8:37-43

Fraser RH, Currie DJ (1996) The species richness-energy hypothesis in a system where historical factors are thought to prevail: coral reefs. Am Nat 148:138-159

Gardner WD (1980) Field assesment of sediment traps. J Mar Res 38:41-52

Hughes IP (1.996) Demographic approaches to community dynamics: a coral reef example. Ecology 77(7):2256-2260

Johannes RE, Wiebe WJ, Crossland CJ, Rimmer DW, Smith SV (1983) Latitudinal limits of coral reef growth. Mar Ecol Prog Ser 1:105-111

Karlson RH, Hurd LE (1993) Disturbance, coral reef communities, and changing ecological paradigms. Coral Reefs 12 : $117-125$

Lang JC (1973) Interspecific aggression by scleractinian corals. 2. Why the race is not only the swift. Bull Mar Sci 23:260-279

Lang JC, Chornesky EA (1990) Competition between scleractinian reef corals - a review of mechanisms and effects In: Dubinsky Z (ed) Coral reefs: ecosystems of the world 25. Elsevier, Amsterdam, p 209-252

Larsson U, Blomqvist S, Abrahamsson B (1986) A new sediment trap system. Mar Ecol Prog Ser 31:205-207

Lewis SM (1986) The role of herbivorous fishes in the organization of a Caribbean reef community. Ecol Monogr 56 $183-200$

Logan A (1984) Interspecific aggression in hermatypic corals from Bermuda. Coral Reefs 3:131-138

Meesters EH, Noordeloos M, Bak RPM (1994) Damage and regeneration: links to growth in the reef-building coral Montastrea annularis. Mar Ecol Prog Ser 112 $119-128$

Meesters EH, Wesseling I, Bak RPM (1997) Coral colony tissue damage in six species of reef-building corals: partial mortality in relation with depth and surface area. J Sea Res 37:131-144

Menge BA (1995) Indirect efferts in marine rocky intertidal interaction webs: patterns and importance. Ecol Monogr $65: 21-74$ 
Miller TE, Travis JT (1996) The evolutionary role of indirect effects in communities. Ecology 77:1329-1335

Müller K (1979) Inter relaciones entre la salinidad y la temperatura en la Bahía de Santa Marta. An Inst Inv Mar Punta Betín 11:219-226

Nandakumar K, Tanaka M, Kikuchi T (1993). Interspecific competition among fouling organisms in Tomioka Bay, Japan. Mar Ecol Prog Ser 94:43-50

Porter JW, Targett NM (1988) Allelochemical interactions between sponges and corals. Biol Bull 175:230-239

Richardson CA, Dustan P, Lang JC (1979) Maintenance of living space by sweeper tentacles of Montastrea cavernosa, a caribbean reef coral. Mar Biol 55:181-186

Rogers CS (1990) Responses of coral reefs and reef organisms to sedimentation. Mar Ecol Prog Ser 62:185-202

Romano SL (1990) Long-term effects of interspecific aggression on growth of the reef-building corals Cyphastrea ocellina (Dana) and Pocillopora damicornis (Linnaeus). J Exp Mar Biol Ecol 140:135-146

Russ GR (1982) Overgrowth in a marine epifaunal community: competitive hierarchies and competitive networks. Oecologia (Berlin) 53:12-19

Rützler K, Muzik K (1993) Terpios hoshinota, a new cyanobacteriosponge threatening Pacific reefs. Scient Mar 57: $395-403$

Sammarco PW (1982) Echinoid grazing a structuring force in coral communities: whole reef manipulations. J Exp Mar Biol Ecol 61:31-55

Sammarco PW, Coll JC, La Barre S (1985) Competitive strategies of soft corals (Coelenterata: Octocorallia). II. Variable defensive responses and susceptibility to scleractinian corals. J Exp Mar Biol Ecol 91:199-215

Schoener TW (1983) Field experiments on interspecific competition. Am Nat 122:240-285

Schulte BA, de Nys R, Bakus GJ, Crews P, Eid C, Naylor S, Manes LV (1991) A modified allomone collecting apparatus. J Chem Ecol 17:1327-1332

Sheppard CRC (1981) Reach of aggressively interacting corals, and relative importance of interactions at different depths. Proc 4th Int Coral Reef Symp 2:363-368

Sih A, Crowley P, McPeek M, Petranka P, Strohmeier K (1985) Predation, competition and prey communities: a review of field experiments. Annu Rev Ecol Syst 16:269-311

Sokal RR, Rohlf FJ (1981) Biometry. The principles and practice of statistics in biological research, 2nd edn. WH Freeman and Co, New York

Suchanek TH, Carpenter RC, Witman JD, Harvell CD (1983) Sponges as important space competitors in deep Caribbean coral reef communities. In: Reaka ML (ed) The ecology of deep and shallow coral reefs. Symposia series for

Editorial responsibility: Otto Kinne (Editor),

Oldendorf/Luhe, Germany undersea research 1, NOAA/NURP, Rockville, MD p 55-60

Sullivan B, Faulkner DJ, Webb L (1983) Siphonodictine, a metabolite of the burrowing sponge Siphonodictyon sp. that inhibits coral growth. Science 221:1175-1176

Targett NM (1988) Allelochemistry in marine organisms: chemicaI fouling and antifouling strategies. In: Thompson MF, Sarojini R, Nagabhushanam R (eds) Marine biodeterioration: advanced techniques applicable to the Indian Ocean. Oxford \& IBH Publishing Co, New Delhi. p 609-617

Thompson JE (1985) Exudation of biologically-active metabolites in the sponge Aplysina fistularis. I. Biological evidence. Mar Biol 88:23-26

Tomascik T, Sander F (1987) Effect of eutrophication on reefbuilding corals. II. Structure of scleractinian coral communities on fringing reefs, Barbados, West Indies. Mar Biol $94: 53-75$

van Duyl $F$ (1985) A.tlas of the living reefs of Curaçao and Bonaire (Netherlands Antilles). Uitgave Natuurwetenschappelijke studiekring voor Suriname en de Nederlandse Antillen 117:37

Van Veghel MLJ, Cleary FLR, Bak RPM (1996) Interspecific interactions and competitive ability of the polymorphic reef-building coral Montastrea cavernosa. Bull Mar Sci 58 $792-803$

Vicente VP (1990) Overgrowth activity by the encrusting sponge Chondrilla nucula on a coral reef in Puerto Rico. In: Rützler K (ed) New perspectives in sponge biology. Smithsonian Institution Press, Washington. DC, p $436-442$

Von Prahl H. Erhardt H (1985) Colombia, corales y arrecifes coralinos. FEN Colombia, Bogota

Walker RP, Thompson JE, Faulkner DJ (1985) Exudation of biologically-active metabolites in the sponge Aplysina fistularis. II. Chemical evidence. Mar Biol 88:27-32

Wilkinson CR, Cheshire AC (1990). Comparisons of sponge populations across the Barrier reefs of Australia and Belize: evidence for higher productivity in the Caribbean. Mar Ecol Prog Ser 67:285-294

Wilkinson L (1989) Systat: the system for statistics. Systat, Inc, Evanston, IL

Zea S (1987) Esponjas del Caribe Colombiano. Un catalogo sistematico y una guia de campo. Edited by Catálogo Científico, Bogota

Zea S (1994) Patterns of coral and sponge abundance in stressed coral reefs at Santa Marta, Colombian Caribbean. In: van Soest RWM, van Kempen ThMG, Braekman JC (eds) Sponges in time and space. Balkema, Rotterdam, p 257-264

Submitted: January 12, 1998; Accepted: September 9, 1998

Proofs received from author(s): December F, 1998 